Economic Discussion Papers

\title{
The Start-Up and Growth Stages in Enterprise Formation: The "New View" of Dividend Taxation Reconsidered
}

\author{
Vesa Kanniainen \\ University of Helsinki and HECER \\ Seppo Kari \\ Government Institute for Economic Research \\ and \\ Jouko Ylä-Liedenpohja \\ University of Tampere and CESifo
}

Discussion Paper No. 53

February 2005

ISSN 1795-0562

HECER - Helsinki Center of Economic Research, P.O. Box 17 (Arkadiankatu 7), Fl-00014 University of Helsinki, FINLAND, Tel +358-9-191-28780, Fax +358-9-191-28781, E-mail info-hecer@helsinki.fi, Internet www.hecer.fi 


\title{
The Start-Up and Growth Stages in Enterprise Formation: The "New View" of Dividend Taxation Reconsidered*
}

\begin{abstract}
A model of a life-cycle of an enterprise is introduced. Owing to substantial early-stage uncertainty, the initial cost of capital is greater than the cost of capital in the expansion stage. Tax effects on enterprise formation, entrepreneurial effort and quality, and on capital costs are derived both for an incorporated enterprise and a sole proprietor. For an incorporated enterprise (i) the entrepreneur's ability threshold rises with the tax rate of the corporate form, (ii) the start-up investment is not affected by undervaluation, but the discouragement engendered by dividend taxation is compensated by realization-based capital gains tax, (iii) with undervaluation, the expansion-stage cost of capital corresponds to the Johansson-Samuelson tax which is lower than the new view suggests, (iv) without undervaluation, the dividend tax provides a boost to investment in the expansion stage.
\end{abstract}

JEL Classification: $\mathrm{H} 25$

Keywords: taxation of start-up enterprises

Vesa Kanniainen

Department of Economics

FI-00014 University of Helsinki

FINLAND

e-mail: vesa.kanniainen@helsinki.fi
Jouko Ylä-Liedenpohja

Department of Economics and

Accounting

FI-33014 University of Tampere

FINLAND

e-mail: jouko.yla-liedenpohja@uta.fi

Seppo Kari

Government Institute for Economic Research

P.O.Box 1279

FI-00101 Helsinki

FINLAND

e-mail: seppo.kari@vatt.fi

* This paper is an outgrowth of another paper with a different focus and presented at the 58th IIPF Congress in Helsinki in 2002 and at the Third Norwegian-German Seminar on Public Economics, CESifo, Munich, June 20-21, 2003. The authors are grateful to Geremia Palomba, Sören Bo Nielsen and other participants for comments on that paper. Vesa Kanniainen acknowledges financial support from Yrjö Jahnsson Foundation and Jouko Ylä-Liedenpohja from Nordisk skattevitenskapelig forskningråd. 


\section{Introduction}

Entrepreneurial investors, outsiders or entrepreneurs themselves, seek their reward in the form of funds freed up from their existing businesses and to transfer them to promising new ventures. That is why they call for lower corporate, dividend and capital gains taxes. Governments are not necessarily interested in lower taxes on income from capital, but highly interested in the likely effects on investment activity and new firm formation resulting from changes in tax policies. Applied tax theory on the cost of capital for investments centres on the issue of whether double taxation of dividends matters for marginal investments (the old view) or whether it is that of retained earnings (the new or trapped equity view), the dividend tax falling upon inframarginal investments. ${ }^{1}$ It therefore distances itself from the pertinent entrepreneurial issues. In particular, mainstream analysis has largely eluded questions as to what extent corporation tax, dividend tax and capital gains tax have separate roles during the life-cycle of entrepreneurial ventures.

Entrepreneurs adopt the role of risk-taking by establishing and running their own enterprises, providing effort and private money to undertake investment decisions. Thus, it is important to understand in what way taxes affect enterprise formation, the quality of entrepreneurs and their effort. Do taxes erect an entry barrier? How do they interact with the investment choices of start-up entrepreneurs facing failure risk? In what way do taxes influence those enterprises which survive to the expansion stage? Unfortunately, most existing tax analysis has dealt with publicly traded mature companies and is therefore inadequate as it lacks the relevant links to the intrinsic characteristics of a start-up enterprise.

The area of taxation and enterprise formation has not, however, been completely neglected. Kanbur (1979), one of the first to introduce a model of entrepreneurship and occupational choice, argued that progressive taxation tends to increase market entry of entrepreneurs if risk aversion is high. One can, however, challenge the view behind this result, i.e. that progressive taxation could provide a form of insurance for risky activity at the start-up stage. One should, however, note that entrepreneurs working on a single project cannot benefit from loss offset provisions to the same extent as companies with several uncorrelated projects. In his analysis of the birth and death of firms, King (1989) assumes that the implementation of an innovation, a business idea, requires a corporate form and either the sale of equity to the outside suppliers of finance or the sale of the business idea to an existing mature company. The corporate form entails an additional tax beyond the sole proprietor. But then the tax is capitalized in the market price of the equity, which is trapped in the corporate form. Dealing with a mature company results in an implicit tax caused by the cost of bureaucracy. The larger the additional tax on companies, the smaller the proportion of business ideas that lead to the formation of new companies. For a given corporate tax structure, a joint distribution of bureaucracy costs

\footnotetext{
${ }^{1}$ The two views are summarized by Auerbach (1983). The "new view" was developed by King (1974, 1977), Bergstöm and Södersten (1977), Auerbach (1979) and Bradford (1981).
} 
and the profitability of new ideas defines the birth rate of new companies in King (1989).

Sinn (1991a,b) provides an important balancing contribution to the old and new views, describing a dividend tax induced evolution of a firm. The firm is set up with external equity, but because there is a dividend tax the firm underinvests in respect of its long-run stock of capital, thus corroborating the old view. Thereafter, the firm enters a purely internally financed growth phase, during which no dividends are paid and no new shares are issued. Having reached its long-run optimal stock of capital, the new view applies. The firm distributes all its profits unless new profitable investment opportunities emerge. Dietz (2003) extends the Sinn framework in a general equilibrium framework.

Some studies have addressed the optimal taxation of enterprises under asymmetric information (Moresi (1998)). Such papers show that market entry and entrepreneurial efforts are important mechanisms which are absent from company tax models, which focus on the share price under taxation. Gordon (1998) has argued that entrepreneurs have access to methods of transforming labor income to capital income. ${ }^{2}$ Ilmakunnas and Kanniainen (2001) have explored the implications of differential insurance on labor and business risks. Keuschnigg and Nielsen $(2003,2004)$ have studied tax effects on venture capital-backed firms.

The economics of unincorporated enterprises and closely held corporations with a dominant owner has received less attention than analyses of publicly traded mature companies. Yet there are fundamental differences between an unincorporated enterprise and a mature company. They operate in different stages of the life-cycle of a firm. One approach is to think of an owner-managed enterprise as a premature prototype of a mature company, though it may never develop to that stage. Indeed, empirical figures indicate that about half of new start-ups default or vanish within the first five years of their life-cycle (Geroski (1995), EUROSTAT (1996)). This means also that the economics of an owner-managed enterprise is different from that of a mature corporation with diversified share ownership and a management team working on an incentive scheme. Limited ability to bear and share risks also restricts access to markets for individuals who face substantial uncertainty in the early stage of the project. ${ }^{3}$ This is different from an enterprise in the mature stage, having a proven track record on success and being able to rely on outside capital markets to finance its expansion investment and managing risks by diversified ownership. Coelho, De Meza and Reyniers (2004) have, however, argued that entrepreneurs may be subject to unrealistic optimism.

The current paper develops a framework for an enterprise run by an owner-

\footnotetext{
${ }^{2}$ We argue below that untaxed private benefits also create a source of tax-free income for entrepreneurs, compensating somewhat the unobservability of the effort cost.

${ }^{3}$ When the project is fully financed from outside sources in conditions of asymmetric information, the problem is a different one. Low-quality projects are subsidized by high-quality projects (de Meza and Webb (1999)). As the entrepreneurs do not have a reputation or outside assets to be pledged as collateral, outside financiers face a lemon's problem, distorting the early cost of capital.
} 
manager. The life-cycle of an enterprise is assumed to have both a start-up phase and an expansion phase with different technologies arising from a learning effect. Unsuccessful ideas are wiped out. Only successful ideas can lead to an expansion stage, allowing the entrepreneur to cash profit, say, via an IPO. While earlier studies on tax effects mostly worked with models which abstract from business risks, we introduce entrepreneurial risk. However, the well-known Domar-Musgrave argument does not apply in the current context, because the government does not share losses from the start-up phase and no insurance is available for the genuine business risk for moral hazard reasons.

Our major results are: for an incorporated enterprise (i) the entrepreneur's ability threshold rises with the tax rate of a uniform rate structure, (ii) the startup investment is not affected by undervaluation, but the discouragement engendered by dividend taxation is compensated by realization-based capital gains tax, (iii) with undervaluation, the expansion-stage cost of capital corresponds to the Johansson-Samuelson tax, which is lower than the new view suggests, (iv) without undervaluation, the dividend tax provides a boost to investment in the expansion stage. Moreover, whenever the dividend tax is lower than the (discounted) capital gains tax, the corporate tax system does not distort the incorporation of enterprises in the Harberger sense.

Section 2 presents the ingredients of the model without taxation, focusing on the career choice of individuals between risky entrepreneurship and a secured outside option. Section 3 introduces the classical taxation of corporations under the key assumption of the new view and explores whether the tax system creates an entry barrier in general and whether corporation tax works against the incorporation of companies. Section 4 concludes.

\section{Model of an entrepreneur}

Motivation. Before being able to analyze fruitfully the taxation of an enterprise, it is necessary to have an appropriate model of an enterprise without taxation. There are reasons why the analysis of an entrepreneur cannot be properly carried out in a model of an incorporated company. First, we need to consider a firm where the owner operates as an active manager. ${ }^{4}$ Second, an entrepreneurial project typically requires consecutive decisions, including the initial "sweat" effort in planning and financial injection, followed by the subsequent setting-up of the ultimate production and marketing facilities. ${ }^{5}$ Third, the risk profile has an intertemporal dimension in that uncertainty is greatest at the early stages (Hall (2002)). After the initial stage, the entrepreneur obtains a signal of the project's success. As in risky projects, the subsequent decisions

\footnotetext{
${ }^{4}$ The owner may have sold, say, a minority of shares to investors but typically the shares are not listed on the main list of stock exchange.

${ }^{5} \mathrm{~A}$ discrete formulation appears to be somewhat more illuminating than a continuous one. Moreover, introducing uncertainty and information revelation changes the expansion analysis and allows for dividend determination within the growth phase, absent from a determistic case, cf. Sinn (1991a).
} 
are conditional on success in the earlier stages; the validity of a deterministic framework is limited to risk-free-projects. Following from the intertemporal risk profile, projects which are able to attract outside finance face a lemon's premium or discount on their early cost of finance. These arise from informational asymmetry and distort market entry and project quality due to the implied cross-subsidization identified by DeMeza and Webb (1999). Such a distortion is absent if entrepreneurs have access to equity of their own, the case studied by our paper. Fourth, a substantial proportion of enterprises fail in the initial state. A successful enterprise, having passed the initial stage, can choose between how much to distribute in dividends and how much to invest in expansion. Fifth, though the initial effort required from the entrepreneur may be compensated by private benefits arising in the later stages of a successful project, it represents a sunk cost and cannot be recouped in the case of a failure. For these reasons, a model of an enterprise with a start-up phase cannot be copied from the theory of a mature corporation.

Ability distribution Potential entrepreneurs possess a project idea. There is a continuum of entrepreneurs, indexed by ability $a \in(0, \bar{a})$. This ability is reflected in an agent-specific skill. Some are more productive and innovative than others. They all are risk-neutral. They face a career choice between forming an enterprise and entering the labor market. Commitment to entrepreneurship requires an initial effort, $e>0$, and an initial investment, $k>0$, at time $t=0$. Effort represents a non-replicable input, like sweat capital. ${ }^{6}$ The effort cost is convex, $c(e)=\frac{1}{2} e^{2}$.

The value of an entrepreneurial career The allocation of individuals to risky industries occurs by self-selection. An investment $k$ in a risky project provides access to a risky return. With a probability of $\pi>0$, the project will be a success. If it succeeds, the entrepreneur gets returns of $k+a f(e, k)>k$. With a probability of $1-\pi$, the project will fail and yield a zero return. The risk affects the career choice and the start-up investment. It is assumed that $f(e, k)$ is jointly concave in $e$ and $k$. There are three stages: $t=0,1,2$. At stage $t=0$, individuals make their career choice. Those choosing entrepreneurship provide an effort, $e$, to work with their business idea and make the initial investment, $k$. The first stage provides the entrepreneurs with a signal of the profitability of their idea. Only enterprises with a positive signal can expand; those with a negative signal leave the market. Those with a positive signal have the option to allocate the first-stage cash flow as an immediate dividend, $d$, or to expansion investment, $K>0$. To highlight the idea that risks are greatest at the early stage of a project, we assume that the second-stage return is not subject to uncertainty.

Thus, to emphasize the fundamental differences between start-up enterprises and mature companies in terms of the ability and effort needed and the risk involved, we introduce different technologies, af $(e, k), F(K)$, with access to the

\footnotetext{
${ }^{6}$ In this respect, our model offers a wider view of firm birth than, say, King (1989).
} 
second obtainable stochastically. Intuitively, as the start-up technology is a prototype of the mature company, the difference arises from learning and business experience as first discussed by Arrow (1962), yet from a somewhat different angle. To survive successfully into an expansion stage, it is also necessary for the entrepreneur to develop a proper organizational set-up for his business, a well functioning entrepreneurial or corporate culture.

The second-stage technology can be viewed as an advanced version of the first-stage technology and formally expressed as $F(a, x)=a f(0, x)$. It does not require specialized inputs. Hence, no effort is needed and the return is given by $F(a, K)$ which is increasing and strictly concave in $a$ and $K$. To economize in notation, we work with $F(K)$ in the following, surpressing $a$.

If the entrepreneur is successful in the first stage (of the enterprise life-cycle), in the second stage he also has access to private benefits, $b K$, assumed to be related to the amount invested in the second stage, $b>0 .{ }^{7}$ Note, however, that private benefits in later stages do not represent a free lunch for surviving entrepreneurs who had to undertake costly efforts in the early stages.

We assume that there is full depreciation of the first-stage capital $k$, and that the depreciation charges of the second-stage capital investment $K$ are fully reinvested. This distinction also highlights the heterogeneity of capital over the lice-cycle of the enterprise. In the second production stage, the successful enterprise accumulates net assets, $\Delta V=F(K)+K-k$. It can be sold or the firm can go public through an IPO with its shares traded on the stock market, allowing the entrepreneur to exit. ${ }^{8}$ The time line of our three-stage model is presented in Figure 1.

Assume separable linear utility (risk-neutrality) of an entrepreneur and let $V$ denote the value of an entrepreneurial career in risky industries. The cash flows in periods 1 and 2 for a risky career are

$$
d=a f(e, k)+k-K ; \quad D=F(K)+K .
$$

Let $r=$ the interest rate. Only the first-stage cash flow $d$ is subject to uncertainty. After the first stage, the entrepreneur obtains a signal of the project's success. The second-stage cash flow $D$, at the liquidation of the project, is conditional on success in the initial period but it is deterministic. In terms of

\footnotetext{
${ }^{7}$ Jensen and Meckling (1976) identify private benefits as a source of agency costs between owner-managers and external shareholders. Once shares in a firm are sold to outsiders, the entrepreneur has an incentive to exploit the resourses of the firm for his consumption, reducing his labor input because he has to share with the outsiders the profit he makes. However, the value of the enterprise is adjusted for the agency cost. In our model, there is no such conflict of interest. However, our model allows for non-taxed private benefits because surviving entrepreneurs when investing in legitimate business expenses, for example, have access to private consumption using the resources of the enterprise. Equally relevant, the founding entrepreneur gets personal satisfaction from working in his own firm. Parker (2004) reviews studies on income differences between entrepreneurs and workers. Comparisons are problematic for several reasons. For example, unsuccessful entrepreneurs are not shown in statistics.

${ }^{8}$ In standard models, the technology is taken to be invariant to the corporate culture and learning in the internal organization of production. This is diffrent in our model.
} 


\begin{tabular}{|llc|}
\hline Start-up stage & Expansion stage & Mature stage \\
Career choice & First production & Second production \\
Start-up investment & Signal of profitability \\
Effort & $\begin{array}{l}\text { Expansion investment } \\
\text { Profit distribution }\end{array}$ \\
\hline
\end{tabular}

Figure 1: Time line of the model

backward induction, the project value at the beginning of the second stage is

$$
V_{1}(b)=-K+\frac{D+b K}{1+r}
$$

Then, provided the occupational choice satisfies the participation constraint, the optimal risky career satisfies

$$
V_{o}(a)=\max _{e, k}\left(-(c(e)+k)+\pi \frac{1}{1+r}\left[a f(e, k)+k+V_{1}^{*}(b)\right]\right),
$$

where $V_{1}^{*}(b)=\max _{K} V_{1}(b)$. Note that $V_{o}(a)$ should be read as the life-time value of the entrepreneurial occupation of an individual with entrepreneurial ability $a$ and given that he invests optimally in both stages of his life-cycle.

It becomes important to analyze separately the costs of capital for the first stage and the second stage. The optimal expansion investment of surviving enterprises satisfies

$$
F_{K}(K)=r-b .
$$

This expression represents the second-stage cost of capital. Private benefits reduce it as they operate as perfect substitutes for cash dividends. ${ }^{9}$ Note, however, that this effect is relevant only for successful enterprises.

The cost of capital for the start-up investment is

$$
f_{k}(e, k)=\left(\frac{1}{a}\right)\left[\frac{1-\pi}{\pi}+\frac{r}{\pi}\right]
$$

The cost of capital is the skill-scaled cost of depreciation multiplied by the odds of failure, $(1-\pi) / \pi$, and the risk-adjusted interest lost, $r / \pi$. High failure risk (low $\pi$ ) discourages the initial investment. There are two reasons why the initial cost of capital is greater than the expansion-stage cost of capital,

\footnotetext{
${ }^{9}$ For tax analysis, their role is important as they are unobservable and represent an untaxed source of entrepreneurial income.
} 
Lemma 1 The initial-stage cost of capital is greater than the expansion-stage cost of capital when risks are greater in the early stages of an enterprise and because surviving enterprises provide private benefits for entrepreneurs. Moreover, less able entrepreneurs have a higher cost of capital.

Moreover, note that when the two conditions (4) and (5) hold with equality, they describe an interior solution for the optimal dividend along the growth path. When optimal $\widehat{e}, \widehat{k}$ and $\widehat{K}$ are determined, the optimal dividend is obtained from $\widehat{d}=a f(e, \widehat{k})-\widehat{K}$. This can be contrasted with the model by Sinn (1991a) where the firm pays no dividend along the expansion path. We can also have a corner solution with all cash flow invested and no dividends paid out if the second-stage investment is expected to be highly profitable with $F_{K}(\widehat{K})>r-b$. Excluding the possibility of a negative dividend (share issue), the cost of capital does not determine the amount invested. Thus, along the growth path, there is an optimal dividend policy, $\widehat{d} \geq 0$. With regard to the dividend decision, our model deviates from Sinn (1991a), whose firm has the same investment opportunities over time. In our model, the second investment opportunity arises only after the first investment opportunity has been tested.

Large private benefits, when related to enterprise size, reduce cash dividends in the early stage and raise investment. With $c(e)=\frac{1}{2} e^{2}$, the first-order condition for effort satisfies

$$
f_{e}(e, k)=\left(\frac{1}{a}\right)\left[\frac{1}{\pi}+\frac{r}{\pi}\right] e .
$$

The left-hand side represents the marginal return on effort. The right-hand side is the product of the initial cost of capital and the marginal cost of effort, i.e. its full opportunity cost. A high first-stage cost of capital reduces the entrepreneurial effort.

We now characterize another key decision of the entrepreneur, i.e. entry, the career choice.

Career choice Market entry is endogenous and the entry threshold can be stated in terms of the marginal entrepreneurial ability, $a$. Entrepreneurs compare various candidate projects using the discount rate, $r$, introduced above, to provide a ranking. Those who enter as entrepreneurs evaluate the expected value of their career, $V_{o}(a)$, and compare it to the life-time value of an outside option, $w$. This can be viewed as secured labor income (insured by social insurance). Then, the entry threshold, which depends on the quality of a candidate as an entrepreneur, is given by the condition

$$
V_{o}(a) \geq w .
$$

Proposition 2 The value of an entrepreneurial career is monotonically increasing in the ability $a$.

Proof. Consider an individual with marginally higher entrepreneurial ability than an individual with ability $a$, i.e. having $a+d a$. Then, his initial cost of 
capital in (5) is lower; similarly his private cost of effort is lower. Consequently, he provides more effort and invests more in the start-up stage. However, because of the envelope theorem, these effects cancel out in the value of an entrepreneurial career. The direct effect is given by $\partial V_{o}(a) / \partial a=\frac{\pi}{1+r} f(\widehat{e}, \widehat{k})$ which is positive.

The most able agents thus become entrepreneurs and they have a lower cost of capital, given that the outside option is unrelated to entrepreneurial skill. For the marginal entrepreneur with ability $a^{m}, V\left(a^{m}\right)=w$ holds. This completes our framework.

\section{Classical tax system}

Tax authorities face a particularly hard task in designing a tax structure for entrepreneurs. They obviously want to avoid distorting enterprise formation and its quality and subsequent capital investment. They might want high-ability types to become entrepreneurs. They want to balance between the taxation of early returns in the form of corporation tax and dividend tax and later returns, say capital gains from an IPO, when the entrepreneur quits his project. Finally, they want to avoid penalizing effort, whilst recognizing that part of the subsequent gains arise in terms of unobservable private benefits.

Incorporated enterprise Tax treatment differs in the case of an incorporated company compared to a sole proprietor. We consider first the case of an incorporated company. Taxes from enterprises are collected at the firm level and the entrepreneur level. Let $\tau_{c}, \tau_{d}, \tau_{g}, \tau_{w}$ denote the tax rates on profits, dividends, capital gains and earned income. ${ }^{10}$ Tax on interest income is not explicitly introduced.

We first develop the expression for tax liability. As the effort cost is private information, the profits tax base in the first stage of a successful firm is af $(e, k)$, while under the classical system the dividend tax base is $d=\left(1-\tau_{c}\right) a f(e, k)+k-$ $K$. The second-stage profits tax falls on $F(K)$. The capital gains tax liability of the expansion stage is based on the after-corporation-tax cash flow $\left(1-\tau_{c}\right) F(K)$, adjusted for the difference in the terminal and initial asset values. The secondstage return is assumed to be collected as a capital gain.

Consider a case where the surviving enterprise is acquired by another firm. What is the market value of an enterprise whose ownership is sold through an IPO? The widely adopted principle of affiliation privilege indicates that mergers can be motivated by tax considerations (Sinn (1987), King (1989)). The trapped equity view suggests that it is cheaper to expand by purchasing companies than by buying new capital goods. This is the undervaluation result. The rate of undervaluation is given by $\frac{1-\tau_{d}}{1-\tau_{g}} .^{11}$

\footnotetext{
${ }^{10}$ We consider enterprises with a domestic owner. Hence, the mechanisms of an open economy in the form of foreign ownership do not arise.

${ }^{11}$ The relevant undervaluation for the creation of incorporated companies is caused by the extra taxes levied on the corporate form, as explained by King (1989), cf. above.
} 
This view suggests that it is the ultimate owner's taxation which dictated the valuation of the acquired firm. However, one can also suggest that in cases where firms bid for other firms, their reservation price is greater. Let $V_{r}=$ the amount a firm is willing to pay for another firm as an alternative to paying a cash dividend to its owners.

The opportunity cost of each euro of such funds to the owners is $1-\tau_{d}$. Therefore, the after-tax value of such funds is, $\left(1-\tau_{d}\right) V_{r}$. When the retained profit is used instead to acquire another firm, producing output $F(K)$ in the mature stage, its value net of taxes to the owners of the acquiring firm is $\left(1-\tau_{d}\right)\left[\left(1-\tau_{c}\right) F(K)+K\right]$. The equality of the two expressions provides the reservation value of the acquired company

$$
V_{r}=\left(1-\tau_{c}\right) F(K)+K .
$$

Therefore, undervaluation disappears.

The initial investment $k$ qualifies as an expense in the capital gains taxation at the end of the planning horizon. The taxable capital gain in the end is thus ${ }^{12}$

$$
\Delta V_{g}=\left(1-\tau_{c}\right) F(K)+K-k .
$$

However, if the firm is undervalued in the IPO, the founding entrepreneur obtains less than $V_{r}=\left(1-\tau_{c}\right) F(K)+K$ by the amount $-(1-\gamma) V_{r}$ where the parameter $\frac{1-\tau_{d}}{1-\tau_{g}} \leq \gamma$ denotes the rate of undervaluation in the light of the two views. ${ }^{13}$ In classical corporation tax with full expensing of the depreciated firststage capital $k$, the tax liability of a successful incorporated enterprise in a risky industry is thus

$$
\begin{aligned}
T(e, k, K)= & \tau_{c} \frac{a f(e, k)}{1+r}+\tau_{d} \frac{\left(1-\tau_{c}\right) a f(e, k)+k-K}{1+r} \\
& +\tau_{c} \frac{F(K)}{(1+r)^{2}}+\tau_{g} \frac{\gamma\left[F(K)\left(1-\tau_{c}\right)+K\right]-k}{(1+r)^{2}} \\
& +(1-\gamma) \frac{\left(1-\tau_{c}\right) F(K)+K}{(1+r)^{2}}
\end{aligned}
$$

the last term represents the undervaluation caused by the tax system to the owners of the firm to be sold.

Sole proprietor In the case of a sole proprietor, the profits tax is equal to $\tau_{w}$ and there is no separate dividend tax. Moreover, the accumulated retained

\footnotetext{
${ }^{12}$ Note that in our model, $\Delta V_{g}>0$. Government would not share a potential capital loss with an entrepreneur.

${ }^{13}$ We notice that the upper limit of $\gamma$ need not be restricted to being less than 1 . For example, the tax system to be introduced in Finland implies that $\gamma>1$ for domestically controlled companies.
} 
earnings do not generate taxable income when the business is sold. ${ }^{14}$ The tax liability then reads

$$
T(e, k, K)=\tau_{w} \frac{a f(e, k)}{1+r}+\tau_{w} \frac{F(K)}{(1+r)^{2}}
$$

Thus, an incorporated company subject to a proportional dividend and capital gains tax is taxed more heavily than a sole proprietor, unless the progressive taxation of earnings of the latter makes a difference. ${ }^{15}$

In the case of a sole proprietor, the first-order conditions of the entrepreneur's optimization problem reduce to the following conditions for the second- and first-stage cost of capital and for the supply of effort:

$$
\begin{gathered}
F_{K}(K)=\frac{r-b}{1-\tau_{w}} \\
a f_{k}(e, k)=\frac{(1-\pi) / \pi+r / \pi}{1-\tau_{w}} \\
a f_{e}(e, k)=\left[\frac{1 / \pi+r / \pi}{1-\tau_{w}}\right] e,
\end{gathered}
$$

which, as a matter of fact, are the benchmark values of a Johansson-Samuelson tax, taxing all income comprehensively once, including interest income. The tax is neutral with respect to the project choice. ${ }^{16}$

The decision to incorporate Assuming identical cash flows from incorporated and unincorporated businesses, King (1977, ch. 4) concludes that under classical double taxation of dividends, an entrepreneur would never incorporate his business if dividends are the sole form of profit distribution, but he incorporates his business if the double-tax rate of retained earnings is less than the personal tax rate, i.e. if $\left(1-\tau_{c}\right)\left(1-\tau_{g}\right)>\left(1-\tau_{w}\right)$ holds true. Contrasting (8) with (9), we see that the rate of corporation tax $\tau_{c}$ acts in (8) similarly as $\tau_{w}$ affects (9). Hence, either $\tau_{c}$ must be considerably less than $\tau_{w}$ or the cash flows $a f(e, k)$ and $F(K)$ of an incorporated company must accordingly be higher to cover the additional three terms in (8) for the incorporation to take place.

\footnotetext{
${ }^{14}$ We assume no goodwill gains at the instant of realization, which is equivalent to assuming that the subsequent future cash flows satisfy the rate of return requirement but do not create additional value.

${ }^{15}$ There are, however, other potential advantages, for example limited liability for firms which operate as incorporated companies and better liquidity of their share certificates even in the case of a non-listed company.

${ }^{16}$ Under such an income tax with economic depreciation, the tax-rate-invariant valuation of investment projects holds (cf. Sinn 1987, King 1977, 117), though the intertemporal distortion of saving and investment decisions remains.
} 


\subsection{Career choice: entrepreneurship or labor market?}

When incorporated, the entrepreneur maximizes

$$
V^{\tau}=\max _{e, k, K}\left[V_{o}\left(e^{\tau}, k^{\tau}, K^{\tau}\right)-\pi T\left(e^{\tau}, k^{\tau}, K^{\tau}\right)\right],
$$

where the notation with the super index $\tau$ denotes the variables under taxation. Consider first the entrepreneurial choices under a uniform structure of tax rates, $\tau_{c}=\tau_{d}=\tau_{g}=\tau_{w}$. For a choice between the outside option and a sole proprietor (an unincorporated enterprise), the tax structure is neutral, but it need not be neutral in respect of the formation of incorporated companies. In the classical tax system, owing to the double taxation of corporate income, the after-tax enterprise value is lower than the present value of the after-tax outside option with identical cash flows. Though this mechanism is implicitly discussed in the tax literature (Harberger (1962)), it largely abstracts from the question of occupational choice. We therefore report it as a proposition.

Proposition 3 Let $a^{\tau}$ denote the marginal entrepreneurial talent under taxation. Then it follows that under a tax structure with uniform tax rates, i.e. $\tau=\tau_{c}=\tau_{d}=\tau_{g}=\tau_{w}$, there $i s$ a positive relationship between the tax rate and the marginal talent, $\partial a^{\tau} / \partial \tau>0$.

Proof. We prove the result formally in the case where the tax structure is constructed in an ingenious way in that it is neutral in respect of effort choice $e^{\tau}$ and investments $k^{\tau}, K^{\tau}$. Consider the indifference condition for occupational choice under taxation,

$$
V_{o}^{\tau}\left(a^{\tau}\right)=w\left(1-\tau_{w}\right)
$$

or

$$
\begin{aligned}
& -\left(c\left(e^{\tau}\right)+k^{\tau}\right)+\pi \frac{1}{1+r}\left[a^{\tau} f\left(e^{\tau}, k^{\tau}\right)+k^{\tau}+V_{1}^{* \tau}(b)\right] \\
& -\pi\left[\tau_{c} \frac{a^{\tau} f\left(e^{\tau}, k^{\tau}\right)}{1+r}+\tau_{d} \frac{\left(1-\tau_{c}\right) a^{\tau} f\left(e^{\tau}, k^{\tau}\right)-K^{\tau}}{1+r}\right. \\
& +\tau_{c} \frac{F\left(K^{\tau}\right)}{(1+r)^{2}}+\tau_{g} \frac{\left(\gamma F\left(K^{\tau}\right)\left(1-\tau_{c}\right)+K^{\tau}\right)-k^{\tau}}{(1+r)^{2}} \\
& \left.+(1-\gamma) \frac{\left(1-\tau_{c}\right) F\left(K^{\tau}\right)+K^{\tau}}{(1+r)^{2}}\right]-w\left(1-\tau_{w}\right)=0 .
\end{aligned}
$$

We consider the case $\gamma=1$. Introducing $\tau=\tau_{c}=\tau_{d}=\tau_{g}=\tau_{w}$ and deviding throughout by $(1-\tau)$, then differentiating this condition (which is an identity) in respect of the tax rate $\tau$ and ability $a^{\tau}$, gives

$$
\frac{d a^{\tau}}{d \tau}=\frac{a^{\tau} f\left(e^{\tau}, k^{\tau}\right)+\frac{1}{1+r} F\left(K^{\tau}\right)+\frac{(1+r)\left(c\left(e^{\tau}\right)+k^{\tau}\right)}{\pi(1-\tau)^{2}}-\frac{b K^{\tau}+(2+r) k^{\tau}}{(1+r)(1-\tau)^{2}}}{(1-\tau) f\left(e^{\tau}, k^{\tau}\right)} .
$$

We can take it for granted that the three positive terms dominate the last one. ${ }^{17}$

${ }^{17}$ It is fairly obvious that the difference of the third and fourth terms is positive. 
The above proof holds strictly for a tax structure which does not distort the effort choice $e^{\tau}$ and investments $k^{\tau}, K^{\tau}$. However, we expect it to hold more generally. We therefore prove

Proposition 4 Let $a^{m}$ and $a^{\tau}$ denote the marginal entrepreneurial talents in the absence of taxation and under taxation, respectively. Then it follows that under a tax structure with uniform tax rates, i.e. $\tau_{c}=\tau_{d}=\tau_{g}=\tau_{w}$, there is a linear dependence between the marginal entrepreneurial talents

$$
a^{\tau}=\beta_{o}+\beta_{1} a^{m},
$$

where $\beta_{1}$ is a strictly positive constant and greater than one.

Proof. In the absence of taxation, the marginal entrepreneur $a^{m}$ is identified from the condition

$$
-(c(e)+k)+\pi \frac{1}{1+r}\left[a^{m} f(e, k)+k+V_{1}^{*}(b)\right]=w .
$$

Inserting into the indifference condition under taxation, and recalling that $V_{1}^{*}(b)=$ $-K+\frac{F(K)+(1+b) K}{1+r}$, we find that there is a linear dependence between the marginal abilities

$$
a^{\tau}=\beta_{o}+\beta_{1} a^{m} .
$$

Its parameters are given by

$$
\beta_{1}=\frac{\left(1-\tau_{w}\right)}{\left(1-\tau_{c}\right)\left(1-\tau_{d}\right)} \frac{f(e, k)}{f\left(e^{\tau}, k^{\tau}\right)} .
$$

and by

$$
\beta_{o}=\frac{1}{\frac{\pi}{1+r}\left(1-\tau_{c}\right)\left(1-\tau_{d}\right) f\left(e^{\tau}, k^{\tau}\right)} Z
$$

where

$$
\begin{aligned}
Z= & \left(c\left(e^{\tau}\right)+k^{\tau}\right)-\left(1-\tau_{w}\right)(c(e)+k) \\
& +\pi \frac{1}{1+r}\left[\left(1-\tau_{w}\right) V_{1}^{*}(b)-V_{1}^{* \tau}(b)\right] \\
& +\pi \frac{1}{1+r}\left[\left(1-\tau_{w}\right)\left(k-\left(1+\tau_{g}\right) k^{\tau}\right)\right] \\
& +\pi\left[\tau_{d} \frac{-K^{\tau}}{1+r}+\tau_{c} \frac{F\left(K^{\tau}\right)}{(1+r)^{2}}\right. \\
& \left.+\tau_{g} \frac{\left(\gamma F\left(K^{\tau}\right)\left(1-\tau_{c}\right)+K^{\tau}\right)}{(1+r)^{2}}+(1-\gamma) \frac{\left(1-\tau_{c}\right) F\left(K^{\tau}\right)+K^{\tau}}{(1+r)^{2}}\right]
\end{aligned}
$$

We know that under distortive taxes, $e^{\tau}<e, k^{\tau}<k$, and that $K^{\tau}<K$. Thus, $\frac{f(e, k)}{f\left(e^{\tau}, k^{\tau}\right)}>1$. With a uniform tax rate, $\frac{\left(1-\tau_{w}\right)}{\left(1-\tau_{c}\right)\left(1-\tau_{d}\right)}>1$. Therefore, $\beta_{1}>>1$. Moreover, the greater the dividend and the corporate tax rates, the greater the coefficient $\beta_{1}$. This tends to make $a^{\tau}>a^{m}$. Inspection of $Z$ leads us to conclude 
that though there are both positive and negative terms in $\beta_{o}$, there is no reason to doubt that there is positive dependence between $a^{\tau}$ and $a^{m}$ as $\beta_{1}>>1 .^{18}$

What our proposition suggests is that even a uniform tax structure $\tau_{c}=$ $\tau_{d}=\tau_{g}=\tau_{w}$ is distortive in respect of enterprise formation. With identical cash flows, the after-tax enterprise value would be lower in the classical tax system than the present value of the after-tax outside option. The dividend tax is distortionary and affects the career choice of individuals between entrepreneurship and entering the labor force. The non-neutrality of dividend taxation follows from the observation that double taxation of profits reduces the ex ante value of the yet unborn enterprise relative to the after-tax value of the outside option. For the equality $V_{o}^{\tau}\left(a^{m}\right)=w\left(1-\tau_{w}\right)$ to hold, $a^{m}$ must be greater with a uniform tax structure than in the absence of taxation, that is, the new business idea must show greater profitability, cf. King (1989).

With a non-uniform tax structure, an additional distortion is created by the undervaluation at exits. Dividend taxation may thus have larger distortions on enterprise formation than has been previously recognized by the literature emphasizing its capitalization. This mechanism is seldom analyzed in the literature discussing the neutrality of dividend taxation in respect of expansion investments by mature companies, in particular. The exceptions are King (1989), Keuschnigg (2001) and Dietz (2003).

\subsection{Capital costs}

Second-stage cost of capital Consider the investment incentives of incorporated companies. With taxation, the second-stage cost-of-capital transforms into

$$
F_{K}(K)=\frac{r-b}{\left(1-\tau_{g}\right)\left(1-\tau_{c}\right) \gamma}+\frac{1-\gamma}{\left(1-\tau_{g}\right)\left(1-\tau_{c}\right) \gamma}-\frac{\tau_{d}(1+r)-\tau_{g} \gamma}{\left(1-\tau_{g}\right)\left(1-\tau_{c}\right) \gamma}
$$

The second term, in effect a capital loss, captures the undervaluation caused by taxation in the market value of an enterprise, when sold to the next owner. We indeed find that the expansion investment is subject to the standard double taxation effect, $\left(1-\tau_{g}\right)\left(1-\tau_{c}\right)$. Moreover, the expansion investment is sensitive to the relative magnitude of tax rates on dividends and capital gains. To the extent that the enterprise provides untaxed private benefits, these tax effects are mitigated. The dividend tax can be avoided by additional investment. The dividend tax rate is the fraction at which the tax authority participates in the investment expenditure and the effective capital gains tax rate $\tau_{g} \gamma$ is the authority's share of the future returns of the venture. Hence, the entrepreneur cannot avoid taxation of business income forever. The postponed dividends will ultimately be subject to a capital gains tax (cf. Sinn (1987), 94-95).

The perfect undervaluation of the "new view", i.e. with $\gamma=\frac{1-\tau_{d}}{1-\tau_{g}}$ plugged

${ }^{18}$ Note that $\beta_{o} \geq 0$ is not even needed for $a^{\tau}>a^{m}$. 
into (13), results in

$$
F_{K}(K)=\frac{r-b}{\left(1-\tau_{c}\right)} .
$$

That is, the effect of both the dividend tax and the capital gains tax on the cost of capital cancels out in (13). This means that only the corporation tax distorts. Because $r$ is the post-tax rate of interest, the result corresponds to the Johansson-Samuelson tax if the tax rate on interest income equals the corporation tax rate. Also, if $\tau_{w}=\tau_{c}$ holds, the corporation tax does not distort the expansion of incorporated enterprises in the Harberger sense, as can be seen from (10) and (14).

Recall the trapped equity view. In our model, dividend tax can be avoided by investing and taking the deferral gain. The celebrated trapped equity model suggests that the dividend tax is neutral in respect of long-run capital because it is paid anyway, whether profit is distributed or invested. Our model produces the same result in (14). But, with a positive capital gains tax rate, the cost of capital (14) is lower than the standard new view with $F_{K}(K)=\frac{r-b}{\left(1-\tau_{g}\right)\left(1-\tau_{c}\right)}$ suggests. Therefore, capital gains tax provides a boost to expansion investment. The reason is that in our model realization-based capital gains tax does not increase the owner's rate of discount.

If there is no undervaluation, the results change dramatically. With $\gamma=1$ in (13), it is the dividend tax which clearly provides a boost to the expansion investment. This result is just the opposite to the old view, because in our model the marginal source of finance is profits.

First-stage cost of capital Consider next the early investment. The firstorder condition in respect of the initial investment $k$ is given by

$$
a f_{k}(e, k)=\left(\frac{1}{\pi}\right) \frac{1-\pi+r}{\left(1-\tau_{d}\right)\left(1-\tau_{c}\right)}-\left(\frac{1}{1+r}\right) \frac{\tau_{g}}{\left(1-\tau_{d}\right)\left(1-\tau_{c}\right)} .
$$

The dividend tax negatively affects the start-up investment. In the classical tax system, the double tax enters the first-period cost of capital, crossing up not only the post-tax rate of interest, $r / \pi$, as in the Harberger-Sinn model, but also the cost of capital asset $(=(1-\pi) / \pi)$, the owner's initial equity stake. This is because the first-stage enterprise is not a going concern, capital $k$ having a zero scrap value. But, undervaluation of equity does not increase the first-stage cost of capital (15) as Sinn (1991a,b) implicates. ${ }^{19}$ By contrast, we find that realization-based capital gains tax alleviates the double taxation of the initial investment. Because of this, the firm has an incentive to invest more heavily in the beginning. Dietz (2003) identifies a similar effect. It arises from the fact

\footnotetext{
${ }^{19}$ Sinn $(1991 \mathrm{a}, 1991 \mathrm{~b})$ states that the capital loss caused by dividend taxation drives the shadow value of capital below its replacement value $q=1$, indicating a higher cost of capital and higher distortion than in the Harberger case. In a sense the argument is based on a kind of fallacy. Though the shadow price of real capital decreases along the firms's growth path, the market value of the whole firm continuously increases at the owner's rate of discount. Ylä-Liedenpohja (1978) is more explicit on this account.
} 
that the initial investment will be expensed against the owner's capital gains liability in the second period. Therefore, the owner's effective purchase cost of the initial capital asset is $1-\tau_{g} /(1+r)$ of a euro. This is in contrast to the standard new view approach in which the role of accrual-based capital gains tax is to raise the cost of capital via raising the rate of discount, while in our model its role is closer to that of a cash flow tax.

Proposition 5 The first-stage cost of capital is raised by the dividend tax (Sinn (1991a)). The second-stage capital gains tax acts as a balancing force on the first-stage cost of capital.

These results reflect the mechanism whereby dividend tax and capital gains tax represent alternative ways of taxing enterprises. The intertemporal effects of dividend tax and capital gains tax deserve some attention. We find that the opportunity cost of investing in expansion investment $K$ financed from the profits of the first stage is reduced by the dividend tax, as the owner can reduce his dividend tax liability in the first period by investing for the second phase. Capital gains tax on successful firms, however, raises the investment threshold in the second-period by raising the cost of capital of the expansion investment. These effects, however, balance each other perfectly, if there is perfect undervaluation in the sense of the new view at the end of the second period and neither the dividend tax nor the capital gains tax has any effect on the cost of capital (14).

From another angle, a dividend tax tilts the investment program, reducing the early stage investment and market entry, but strengthens the expansion investment, if the old view of its effect on the share value $\gamma=1$ holds true. The Sinn-Harberger model obtains a similar time path. The difference here is that in our model the firm pays dividends on the path, while in Sinn-Harberger model, dividends are paid in the terminal state only.

Assume $\tau_{w}=\tau_{c}$ to facilitate comparison of (15) and (11). We find that the first-stage cost of capital is in fact higher than that for an unincorporated company (11) if

$$
1-\frac{\tau_{g}}{(1+r)^{2}}>1-\tau_{d}
$$

holds true. Then, with a uniform tax structure $\tau_{g}=\tau_{d}$, but with a realizationbased capital gains tax, the Harberger distortion against the initial size of incorporated enterprises holds true. Only in the opposite case

$$
\tau_{d}<\frac{\tau_{g}}{(1+r)^{2}}
$$

which incidentally is effectively achieved under an imputation system for dividends but not for retained earnings, there is no Harberger distortion, but such a system provides a boost to the initial size of incorporated enterprises.

Because unobservable effort cannot qualify for a tax shield, both corporation tax and dividend tax reduce the optimal effort. This can be seen from the tax- 
adjusted first-order condition for effort

$$
f_{e}(e, k)=\left(\frac{(1-\pi)+r}{a \pi}\right) \frac{e}{\left(1-\tau_{d}\right)\left(1-\tau_{c}\right)} .
$$

and contrasting it with (12).

\section{Conclusions}

The paper studies the effect of a classical corporation tax system, with an investor-level dividend and capital gains taxes, on enterprise formation and on the entrepreneur's investment incentives in a three-stage model. At stage $t=0$, the individual makes his career choice as to whether to take the outside option or to enter a risky entrepreneurial career. We find his career choice is affected by the tax system. The higher the additional tax burden levied on the corporate form, the higher the ability threshold of individuals who choose entrepreneurship. The potential undervaluation of the company at the entrepreneur's exit stage additionally increases his entry threshold.

Having chosen his career, the entrepreneur invests for the first stage, financing it with his own funds, and chooses his effort. The standard double-tax effects of dividend taxation arise both for the effort and initial-stage investment, ${ }^{20}$ but the latter discouragement is compensated by the realization-based capital gains tax in the later stage. In fact, we demonstrate that a tax system where the investor-level dividend tax is lower than the present value of the capital gains tax boosts the initial size of incorporated enterprises. Such a tax condition is easily obtained under imputation credits on dividends. Undervaluation does not affect the first-stage investment as often suggested. The second-stage investment is assumed to be financed from the first-stage profits as in the new view model. We show that with undervaluation, the expansion-stage cost of capital corresponds to the Johansson-Samuelson tax and it is therefore lower than the standard new view suggests, but that without undervaluation, the dividend tax provides a boost to investment in the expansion stage. Because of the time path of uncertainty, the initial-stage cost of capital is higher than the expansion-stage cost. Also, less able individuals have a higher initial-stage cost of capital.

\section{References}

[1] Arrow, K.J., "The Economic Implications of Learning by Doing", Review of Economic Studies, 29 (3), 1962, 155-173.

\footnotetext{
${ }^{20}$ The tax effects are somewhat mitigated by cross-subsidization of projects in the case where external funds from uninformed financial intermediation are important (deMeza and Webb (1999)) and the expected private benefits, which nonetheless accrue only where the firm survives to the second investment stage.
} 
[2] Auerbach, A.J., (1979), "Wealth Maximization and the Cost of Capital", Quarterly Journal of Economics, 94, 433-446.

[3] Auerbach, A.J. (1983), "Taxation, Corporate Financial Policy and the Cost of Capital", Journal of Economic Literature, 21, 905-940.

[4] Bergstöm, V. and Södersten, J., (1977), Double Taxation and Corporate Capital Costs, Paper presented at the Econometric Society Meeting, Vienna, 6-9, September 1977.

[5] Bradford, D.F. (1981), "The Incidence and Allocation effects of a Tax on Corporate Distributions", Journal of Public Economics 15, 1-22.

[6] Coelho, M., De Meza D. and D. Reyniers (2004), "Irrational Exuberance, Entrepreneurial Finance and Public Policy", International Tax and Public Finance, 11, 391-417.

[7] De Meza, D. and D. Webb (1999), "Wealth, Enterprise and Credit Policy", The Economic Journal, 109, 153-163.

[8] Dietz, M.D., "Dividend and Capital Gains Taxation in a Cross-Section of Firms", University of St.Gallen, 2003.

[9] Enterprises in Europe, Fourth Report, 1996 (SME Project), EUROSTAT.

[10] Geroski, P.A. (1995), "What do we know about entry?", International Journal of Industrial Organization 13, 421-440.

[11] Gordon, R. (1998), "Can High Personal Tax Rates Encourage Entrepreneurial Activity?", IMF Staff Papers, 45, 49-80.

[12] Hall, B.H. (2002), "The Financing of Research and Development", Oxford Review of Economic Policy, 18, 35-51.

[13] Harberger, A.C., (1962), "The Incidence of the Corporation Tax", Journal of Political Economy, 70, 215-240.

[14] Ilmakunnas, P. and V. Kanniainen (2001), "Entrepreneurship, Economic Risks, and Risk Insurance in the Welfare State", German Economic Review, 2, 195-218.

[15] Jensen, M.C. and W.H. Meckling (1976), "Theory of the Firm: Managerial Behavior, Agency Costs, and Ownership Structure," Journal of Financial Economics, 3, 305-360.

[16] Kanbur, R. (1979), "Entrepreneurial Risk-Taking, Inequality, and Public Policy: An Application of Inequality Decomposition Analysis to the General Equilibrium Effects of Progressive Taxation", Journal of Political Economy, 90, 1-20. 
[17] Kanniainen, V. and M. Leppämäki (2002), Financial institutions and the allocation of talent, Bank of Finland Discussion Papers 2002:5.

[18] Kari, S. (1999), Dynamic Behaviour of the Firm Under Dual Income Taxation, Government Institute for Economic Research, Research Reports 51.

[19] Keuschnigg, C., (2001), "Business Formation and Aggregate Investment, German Economic Review, 2, 31-55.

[20] Keuschnigg, C., and S.B.Nielsen (2003) "Tax Policy, Venture Capital, and Entrepreneurship", Journal of Public Economics, 87, 175-203.

[21] Keuschnigg, C., and S.B.Nielsen (2004) "Taxation and Venture Capital Backed Entrepreneurship", International Tax and Public Finance, 11, 369390.

[22] King, M.A. (1974), "Dividend Behaviour and the Theory of the Firm, Economica, 41, 25-34.

[23] King, M.A. (1977), Public Policy and the Corporation, London: Chapman and Hall.

[24] King, M.A.(1989), "Economic Growth and th Life-Cycle of Firms", European Economic Review, 33, 325-334.

[25] Moresi, S. (1998), "Optimal Taxation and Firm Formation: a model of asymmetric information", European Economic Review, 42, 1525-51.

[26] Parker, S.C., (2004), The Economics of Self-Employment and Entrepreneurship, Cambridge: Cambridge University Press.

[27] Sinn, H.-W. (1987), Capital Income Taxation and Resource Allocation, Amsterdam: North-Holland.

[28] Sinn, H.-W. (1991a), "The Vanishing Harberger Triangle", Journal of Public Economics, 45, 271-300.

[29] Sinn, H-W. (1991b), "Taxation and the Cost-of-Capital; the "Old" View, the "New" View, and Another View", Tax Policy and the Economy 5, $25-54$.

[30] Ylä-Liedenpohja, J. (1978), "Taxes, Dividends and Capital Gains in the Adjustment cost Model of the Firm," Scandinavian Journal of Economics, 80, 399-410. 